\title{
КЛЮЧОВІ КОМПЕТЕНТНОСТІ ЯК ОБ'ЄКТ ДИДАКТИЧНИХ РОЗВІДОК
}

\section{С. А. Федоренко, Л. В. Бутко}

Кременчуцький національний університет імені Михайла Остроградського

вул. Першотравнева, 20, м. Кременчук, 39600, Україна. E-mail: svfedor70@ gmail.com

Сформульовано основні засади необхідності реформування професійно-технічної освіти у розрізі нових еволюційних вимог часу. Розкрито сутність поняття «компетентність» 3 огляду на складність та неоднозначність його змістового наповнення. Проаналізовано сутність поняття «ключові компетентності» та репрезентований зарубіжними та вітчизняними науковцями основний їх перелік. Зауважено, що проблема визначення сутності та переліку ключових компетентностей достатньо грунтовно розроблена в сучасній психолого-педагогічній літературі. Особливу увагу зосереджено на питанні про необхідність у процесі професійної підготовки дотримуватися комплексного формування ключових компетентностей, які сприятимуть становленню особистості майбутнього кваліфікованого робітника як висококласного конкурентоспроможного фахівця.

Ключові слова: компетентність, ключові компетентності, компетенція, професійно-технічна освіта, кваліфікований робітник, професійна підготовка.

\section{КЛЮЧЕВЫЕ КОМПЕТЕНТНОСТИ КАК ОБЫЕКТ ДИДАКТИЧЕСКИХ РАЗВЕДОК}

\section{С. А. Федоренко, Л. В. Бутко}

Кременчугский национальный университет имени Михаила Остроградского

ул. Первомайская, 20, г. Кременчуг, 39600, Украина. E-mail: svfedor70@ gmail.com

Сформулированы основные принципы необходимости реформирования профессионально-технического образования в разрезе новых эволюционных требований времени. Раскрыта сущность понятия «компетентность», учитывая сложность и неоднозначность его содержательного наполнения. Проанализирована сущность понятия «ключевые компетентности» и представленный зарубежными и отечественными учеными основной их перечень. Отмечено, что проблема определения сущности и перечня ключевых компетентностей достаточно основательно разработана в современной психолого-педагогической литературе. Особое внимание сосредоточено на вопросе о необходимости в процессе профессиональной подготовки придерживаться комплексного формирования ключевых компетентностей, которые будут способствовать становлению личности будущего квалифицированного работника как высококлассного конкурентоспособного специалиста.

Ключевые слова: компетентность, ключевые компетентности, компетенция, профессионально-техническое образование, квалифицированный работник, профессиональная подготовка.

АКТУАЛЬНІСТЬ РОБОТИ У сучасних динамічних умовах розвитку суспільства існує необхідність переосмислення професійної підготовки фахівців усіх галузей. Вимогою часу є висока здатність членів суспільства адаптуватися до непрогнозованих соціально-економічних змін. Тому об'єктом дослідження багатьох суспільних наук, у тому числі педагогіки, є особистість. Завдання освіти полягає у формуванні особистості, діяльність якої базується на гуманістичних засадах і визнанні пріоритету людиноцентризму. Не винятком $\epsilon$ професійнопрактична підготовка кваліфікованих робітників, під час якої робиться акцент на суб’єкті навчання - учневі.

Сучасний випускник професійно-технічного навчального закладу згідно Національної доктрини розвитку освіти повинен бути готовим вирішувати нестандартні проблеми, швидко сприймати новації та приймати правильні рішення, самостійно здобувати необхідну інформацію, виділяти проблеми та знаходити шляхи їх ліквідації, аналізувати та застосовувати набуті знання для розв'язання нових завдань; поряд 3 цим повинен мати високі адаптивні здібності і бути підготовленим до виживання у мінливому середовищі.

3 початком нового тисячоліття відбувається перехід оцінювання результатів професійної освіти від понять «професіоналізм», «кваліфікація», «підготовленість», «освіченість», «майстерність» до понять «компетентність», «компетенція» учнів.
На сучасному етапі науковці активно досліджують концептуальні проблеми професійної підготовки фахівців (М. Козяр, В. Кремень, Н. Ничкало, А. Хуторський та ін.), особливості навчального процесу у ПТНЗ (С. Батишев, Н. Божко, О. Буренко, Р. Гуревич, М. Костюченко, А. Литвин, В. Радкевич, В. Скульська, О. Стечкевич та ін.).

Отже, актуальність дослідження зумовлена високою соціальною значущістю підготовки кваліфікованих кадрів та об'єктивною необхідністю подолання суперечностей, наявних у професійному навчанHi.

Мета статті полягає у всебічному розкритті сутності поняття «ключові компетентності» та наведенні переконливих доведень про необхідність комплексного формування ключових компетентностей у майбутніх кваліфікованих робітників.

МАТЕРІАЛ І РЕЗУЛЬТАТИ ДОСЛІДЖЕНЬ. На сьогодні можна констатувати відсутність єдиного підходу до розуміння сутності поняття «компетентність».

У законі України «Про освіту» (2017 р.) компетентність схарактеризована як динамічна комбінація знань, умінь, навичок, способів мислення, поглядів, цінностей, інших особистих якостей, що маркує здатність особи успішно соціалізуватися, провадити професійну та / або подальшу навчальну діяльність.

У «Новому тлумачному словнику української мови» термін «компетентний» потрактовано як «такий, що має досягти знання в будь-якій галузі; який з чим- 
небудь добре обізнаний, тямущий; який грунтується на знанні; кваліфікований; який має повноваження; повноправний, повновладний». У сучасному психологічному словнику за редакцією В. Шапаря «компетентність» визначено як психосоціальну якість особистості, котра означає силу й упевненість, джерелом яких $\epsilon$ відчуття власної успішності та корисності. У соціолого-педагогічному словнику «компетентність» характеризується як психосоціальна якість людини, що дає їй можливість усвідомити свою спроможність ефективно взаємодіяти з оточенням.

Німецький дослідник Х. Шредер кваліфікує компетентність як «готовність, здатність до ефективного спілкування з людьми, відповідальність у ставленні до них (соціальна компетентність), мовні навички (комунікативна компетентність) та професійні знання (фахова компетентність), а також власне «Я» (Якомпетентність)» [1]. І. Зязюн розуміє компетентність як високий рівень умілості, спосіб особистісної самореалізації, деякий підсумок саморозвитку індивіда [2]. О. Пометун під компетентністю розуміє структуровані спеціальним шляхом набори знань, навичок, умінь, і ставлень, що дають змогу людині визначати, тобто ідентифікувати та розв'язувати незалежно від контексту проблеми, характерні для певної сфери діяльності [3]. С. Сисоєва визначає компетентність як інтегровану особистісну якість особи (ії капітал), яка формується на етапі навчання, остаточно сформовується і розвивається у процесі практичної діяльності та забезпечує компетентний підхід до вирішення професійних завдань. Л. Лук'янова пояснює компетентність як міру включення в активну діяльність, здатність ефективно розв'язувати конкретну ситуацію, мобілізуючи при цьому знання, уміння, досвід, поведінкові відносини та цінності», а «здатність діяти» розглядає як «уміння використовувати знання в практичній діяльності».

Сучасна дослідниця I. Дрозіч закцентовує увагу на тому, що компетентність виражена в сукупності компетенцій, залежно від функціональних обов'язків працівника. Останнє десятиріччя вітчизняна педагогічна спільнота, усе частіше замінюючи термін «компетенція», почала використовувати словосполучення, поширене в європейських офіційних документах - «результати навчання», що відображено в низці нормативних і методичних документів (Закон України «Про освіту», Проект Закону «Про професійну освіту»). Цей підхід, на думку I. Дрозіч, дозволяє чітко розмежувати поняття компетентнісного підходу та уникнути можливих термінологічних непорозумінь.

Поняття «компетентність» $є$ інтегративним, що містить такі аспекти: готовність до цілепокладання; готовність до оцінювання; готовність до дії; готовність до рефлексіі.

Ключова (загальноосвітня) компетентність - це певний рівень функціональної грамотності. Ключові компетентності покликані максимально забезпечити соціалізацію молодої людини, утвердження іiі в суспільстві. 3 огляду на це, особливостями їх є сприяння досягненню успіхів, підвищенню якості суспільних інститутів і охоплення всіх сфер суспільного життя.
У формулюванні та визначенні основних видів ключових компетентностей серед науковців не існує одностайної точки зору. При цьому використовуються як європейська, російська системи, так i, власне, українська класифікація. Відсутність узгодженого переліку ключових компетентностей пояснюється передусім різними методологічними підходами і замовленнями конкретної держави щодо підготовки іiі громадян до майбутнього життя. Так, у ході міжнародного проекту «Визначення та відбір ключових компетентностей», який реалізовувався Організацією економічного співробітництва та розвитку і Національними інститутами освітньої статистики Швейцарії та США, чіткого визначення ключових компетентностей вироблено не було.

- Під час симпозіуму Ради Європи з теми «Ключові компетенції для Свропи» було визначено наступний приблизний перелік ключових компетентностей:

- вивчати: вміти отримувати користь 3 досвіду; організовувати взаємозв'язок своїх знань і впорядковувати їх; організовувати свої власні прийоми вивчення; вміти вирішувати проблеми; самостійно займатися своїм навчанням;

шукати: запитувати різні бази даних; опитувати оточення; консультуватися в експерта; отримувати інформацію; вміти працювати з документами та класифікувати їх;

думати: організовувати взаємозв'язок між минулими і реальними подіями; критично ставитися до того чи іншого аспекту розвитку наших суспільств; вміти протистояти непевності та труднощам; займати позицію в дискусіях і виробляти свою власну думку; бачити важливість політичного та економічного оточення, в якому відбувається навчання і трудова діяльність; оцінювати соціальні звички, пов'язані зі здоров'ям, споживанням, а також 3 навколишнім середовищем; вміти оцінювати витвори мистецтва і літератури;

- співпрацювати: вміти співпрацювати та працювати в групі; приймати рішення - вирішувати розбіжності та конфлікти; вміти домовлятися; вміти розробляти і дотримуватися виконання контрактів;

- братися за справу: включатись у проект; нести відповідальність; входити в групу або колектив і робити власний внесок; доводити солідарність; вміти організовувати свою роботу; вміти користуватися обчислювальними і моделюючими приладами;

адаптуватися: вміти використовувати нові технології інформації та комунікації; доводити гнучкість перед обличчям швидких змін; демонструвати стійкість перед труднощами; вміти знаходити нові рішення [4].

В. Хутмахер наводить перелік п'яти ключових компетентностей, прийнятий Радою Свропи, якими «повинні володіти молоді європейці»: політичні та соціальні; міжкультурні; комунікаційні; інформаційні; навчальні.

Польські дослідники виділяють також п’ять ключових компетентностей, серед яких: навчальна, комунікативна, соціальна, діяльнісна і комп'ютерна $[5]$. 
Серед досліджень російських науковців найбільш популярними у визначенні ключових компетентностей $є$ класифікації А. Хуторського і І. Зимньої. Про це свідчить, наприклад, найменування основних ключових компетенцій / компетентностей, які наводяться А. Хуторським: ціннісно-смислова, загальнокультурна, навчально-пізнавальна, інформаційна, комунікативна, соціально-трудова, особистісна компетенція або компетенція особистісного вдосконалення [6].

Зауважимо, що А. Хуторський (разом із В. Краєвським) до поняття «ключові» застосовують термін «компетенції», проте за значенням воно близьке до поняття «ключові компетентності», яке застосовується європейськими науковцями та міжнародними експертами. Вони вважають, що поняття ключових освітніх компетенцій належить до верхнього, загальнопредметного змісту освітніх стандартів, у ключових компетенціях концентровано та взаємозалежно втілені всі компоненти загальнопредметного змісту освіти: реальні об'єкти досліджуваної дійсності; загальнокультурні знання про досліджувану дійсність; загальні й загальнонавчальні вміння, навички, узагальнені способи діяльності. На їхню думку, ключові освітні компетенції конкретизуються на рівні навчальних предметів (освітніх галузей). Відбити у стандартах з окремих навчальних предметів елементи, що відповідають ключовим освітнім компетенціям, - одне із завдань, яке необхідно розв'язати на структурнологічному рівні і втілити як в «Обов'язковому мінімумі змісту освітніх програм», так і у «Вимогах до рівня підготовки випускників» для кожного ступеня навчання та кожного навчального предмета (освітньої галузі) [7].

I. Зимня виділяє групи ключових компетентностей на основі сформульованих в російській психології положень виходячи з того, що людина є одночасно суб'єктом спілкування, пізнання, праці (Б. Ананьєв); що людина проявляється в системі відносин до суспільства, до інших людей, до себе, до праці (В. Мясіщев); що компетентність людини має вектор акмеологічного розвитку (Н. Кузьміна, А. Деркач); що професіоналізм людини містить компетентності (А. Маркова).

Під ключовими компетентностями людини педагоги розуміють спеціально структуровані (організовані) набори знань, навичок, умінь і ставлень, що їх набувають у процесі навчання. Вони дозволяють людині визначати, тобто ідентифікувати і розв'язувати, незалежно від контексту (від ситуації) проблеми, характерні для певної сфери діяльності. Сформовані ключові компетентності людина використовує в різних соціальних та інших контекстах залежно від умов і потреб щодо здійснення різних видів діяльності. Компетентна людина застосовує ті стратегії, які є для неї найприйнятнішими для виконання окреслених завдань. Управління власною діяльністю веде до підвищення або модифікації рівня компетентності людини. Проблема визначення сутності та переліку ключових компетентностей достатньо грунтовно розроблена в сучасній психологопедагогічній літературі. Концептуальною базою визначено три категорії ключових компетенцій: ав- тономна діяльність, інтерактивне використання засобів, уміння функціонувати в соціально гетерогенних групах [8].

Чинний Державний стандарт базової і повної загальної освіти виділяє такі ключові компетентності: уміння вчитися; спілкуватися державною, рідною й іноземними мовами; математична; базові компетентності в галузі природознавства і техніки; інформаційно-комунікаційна, соціальна, громадянська, загальнокультурна, підприємницька; здоров'язбережувальна.

У цьому ж документі визначено перелік предметних (галузевих) компетентностей, а саме: комунікативну, літературну, мистецьку, міжпредметну, естетичну, природничо-наукову, математичну, проектно-технологічну, інформаційно-комунікаційну, суспільствознавчу, історичну, здоров'язбережувальну. Сформовані ключові компетентності $€$ базою для професійної компетентності. Саме на основі та за допомогою ключових компетентностей формуються професійні компетентності, забезпечуючи успішне формування та реалізацію останніх [4].

Разом $з$ тим, ключові компетентності не складаються просто 3 набору предметних та галузевих компетентностей - вони інтегрують галузеві компетентності у складну структурну компоненту, у якій елементи пов'язані між собою різноманітними зв'язками та відношеннями. Знання - це усвідомлена інформація про зовнішнє оточення та внутрішній світ суб'єкта. Навичка - доведений до автоматизму набір дій, набутих у результаті повторення. Уміння - психологічне утворення, що полягає в опануванні суб'єктом певних способів виконання діяльності.

Науковий інтерес викликає праця О. Овчарук, яка запропонувала узагальнену класифікацію головних переліків ключових компетентностей (виокремлених європейськими вченими), розподілених за трьома основними блоками (ключовими групами компетентностей): соціальні, мотиваційні та функціональні [9].

За наслідками діяльності робочої групи українських науковців та практиків запропоновано наступний перелік ключових компетенностей: загальнокультурна, інформаційна, соціальна, навчальна, громадянська, здоров'язберігаюча.

Різними дослідниками цей список постійно вдосконалюється, уточнюється та розвивається. Серед цих доповнень необхідно назвати такі: вміння працювати в колективі, команді; вміння вирішувати проблеми; здатність спілкуватися кількома мовами; здатність організовувати свою діяльність, оцінювати ii тощо. Як зазначає доктор педагогічних наук В. Ягупов, по перше, цей список постійно поповнюється, і даний факт є закономірністю; по-друге, перелік цього списку залежить від конкретного соціуму, тобто список в різних соціумах може кардинально різнитися; по-третє, цей список має індивідуалізований характер, тобто у кожної людини він свій унікальний, неповторний. В-четвертих, сформованість ключових компетентностей $є$ вкрай необхідною умовою для формування людиною інших видів компетентностей і передусім професійної, спеціальної тощо [4]. 
Н. Бібік наводить таку ієрархію компетентностей у навчанні: ключові надпредметні (базові), що спираються на пізнавальні процеси і виявляються в різних контекстах; загальнопредметні - належать до певної сукупності предметів або галузей знань; предметні - часткові щодо вище наведених, які набуваються в процесі вивчення певного предмету [8]. Як зазначає О. Локшина, ведуться дискусії щодо співвідношення цих компетентностей, особливо у секторі професійної освіти. Дослідниця визначає, що «у разі приділення більшої уваги до формування загальних компетентностей під час навчання, підвищується здатність індивідуумів до працевлаштування, а при акценті на формування вузькопрофесійних - зростає якість виконання професійних обов'язків» [10].

Розмежовуючи ключові компетентності майбутнього кваліфікованого робітника Е Зеєр визначає: активну життєву позицію; відповідальність за власний добробут і за стан суспільства, здатність до самоорганізації; орієнтацію на соціальне й професійне самовизначення та самореалізацію; засвоєння основних соціальних навичок, практичність умінь у галузі економіки й соціальних відносин; здатність входження до глобалізованого світу, відкритого інформаційного співтовариства тощо [11].

На переконання Л. Сушенцевої для ключових (базових) компетентностей характерними є такі особливості: багатофункціональність, надпредметність, міждисциплінарність, багатовимірність (особистісні якості, інтелектуальні здібності, комунікативні уміння), опора на певний рівень інтелектуального розвитку (абстрактне, критичне, технічне, економічне мислення, саморефлексія тощо).

Так, сьогодні не можна говорити про успішне навчання будь-якої людини в системі професійної освіти без навчальної компетентності. А адекватне знаходження свого місця в навчальному колективі та реалізація свого соціального потенціалу в навчальному середовищі безпосередньо залежить від соціальної та комунікативної видів компетентності, вміння працювати в учнівському колективі. Дійсно, без ключових компетентностей практично неможливе повноцінне функціонування людини в суспільстві як соціального суб'єкта, успішне оволодіння професією і спеціальністю, навчання протягом життя як навчального суб'єкта, успішна реалізація професійного потенціалу в професійній діяльності як професійного суб'єкта. С. Кравець доводить, що набуття у процесі навчання ключових компетентностей дозволяє фахівцеві діяти в умовах постійного оновлення сфер професійної діяльності, бути здатним до самонавчання, постійного оновлення професійної інформації, саморозвитку та самоадаптації.

У побудові моделі змістовних складових ключових компетентностей, Т. Лобанова виокремлює такі аспекти: 1) системне мислення, бачення розвитку процесів (здатність аналізувати, систематизувати й знаходити оптимальні варіанти вирішення ситуацій, нести відповідальність за прийняті рішення, прогнозувати); 2) аналітичні здібності (логічність, раціональність, послідовність тощо); 3) інноваційність (заданість пропонувати нове, виявляти ініціативу, бути креативним); 4) гнучкість (готовність до змін, здатність швидко й адекватно реагувати на нестандартні ситуації, визначати проблеми та знаходити способи їх вирішення); 5) орієнтація на систематичний розвиток (учіння, сприйняття нових методів і підходів, готовність до аналізу своїх досягнень та поразок, розумне використання досвіду інших); 6) організаторські здібності (вміння керувати, організовувати себе і колектив, визначати пріоритети, планувати); 7) уміння розподіляти час; 8) здатність працювати в команді (вміння підтримувати сприятливий психологічний клімат у колективі тощо); 9) комунікативні ділові уміння; 10) уміння вести перемовини (володіння стратегіями переконуючого впливу, знання етики); 11) орієнтація на відвідувача (уміння працювати 3 відвідувачами, визначати перспективні потреби відвідувачів, вести спілкування з різними категоріями відвідувачів, здатність пропонувати й налагоджувати дружні взаємини $з$ відвідувачами) [12].

Розглядаючи різні погляди на компетентність в освіті, не можемо не звернути увагу на комунікативну компетентність, яка належить до ключових, тобто таких, що мають особливе значення у житті кожної людини.

Комунікативна компетентність $є$ невід'ємною складовою структури змісту мовної освіти і передбачає оволодіння всіма видами мовленнєвої діяльності та вміннями застосовувати відповідні знання у практичній діяльності. Як зазначає Г. Шелехова, «комунікативна компетентність передбачає вміння взаємодіяти 3 людьми й подіями, працювати в групі, презентувати себе засобами мовленнєвої комунікації; вона виражається в умінні самостійно вступати в контакт з будь-яким типом співрозмовника, ураховуючи його особливості; підтримувати контакт у спілкуванні, дотримуючись норм і правил спілкування; слухати співрозмовника, виявляючи повагу до чужої думки; висловлювати, аргументувати і в культурній формі обстоювати власні погляди, стимулювати співрозмовника до продовження спілкування; грамотно розв'язувати конфлікти у спілкуванні; оцінювати успішність ситуації спілкування» [13].

Провідні українські науковці визначають загальнокультурну компетентність однією 3 ключових компетентностей. Утім у процесі професійної підготовки важливо дотримуватися комплексного формування ключових компетентностей, які сприяють становленню особистості майбутнього кваліфікованого робітника як висококласного конкурентоспроможного фахівця.

ВИСНОВКИ. Отже, ключові компетенції - найбільш універсальні культурно вироблені способи дії, що дозволяють особистості розуміти ситуацію, досягати результатів в особистому та професійному житті в умовах конкретного суспільства, тобто практично реалізовувати свою компетентність у певній сфері. 3 позицій компетентнісного підходу рівень освіти визначається здатністю фахівця вирішувати проблеми різної складності на основі сформованих ключових компетентностей.

Опанування теоретико-методологічним змістом ключових компетентностей допоможе педагогічним 
працівникам професійних технічних навчальних закладів здійснювати підготовку кваліфікованого робітника не лише як висококваліфікованого віхівця, а й як різносторонньо розвинутої особистості, готової адаптуватися до різновекторної мінливості та динаміки сучасного життя.

Предметом наступних наукових досліджень можуть стати розвідки у розрізі вивчення особливостей ключових компетентностей, актуальних під час підготовки кваліфікованих робітників 3 урахуванням їх професійної спеціалізації.

\section{ЛІТЕРАТУРА}

1. Schröder H. Theorie und Praxis der Erziehung .München, 1999.

2. Зязюн I. А. Філософія поступу і прогнозу освітньої системи. Педагогічна майстерність : проблеми, пошуки, перспективи : монографія. К. : Глухів : РВВ ГДПУ, 2005. С. 8-10.

3. Пометун О. I. Компетентнісний підхід - найважливіший орієнтир розвитку сучасної освіти. Pidна школа. 2005. № 1. С. 65-69.

4. Ягупов В. Ключевые компетентности: понятие, сущность, содержание, классификация и требования к выпускникам профессиональнотехнического образования. Науковий вісник. 2012. № 4. C. 12-18.

5. Matusz M. Kompetencje informacyjne nauczycieli i uczniw. Edukacja Technika - informatyka - edukacja / pod red. W.Walata. Rzeszow : Uniwersytet Rzeszowski, 2008. Tom X. Teoretyczne i praktyczne problemy edukacji informatycznej. S. 191-192.

6. Хуторской А. В. Ключевые компетенции и образовательные стандарты : 2002 г. : Доклад на отделении философии образования и теории педагогики РАО. Интернет-журнал «Эйдос». 2002. : http://www.eidos.ru/journal/2002/0423.htm (дата звернення: 23.03.2019)

7. Краевский В. В. Хуторской А. В. Предметное и общепредметное в образовательных стандартах. Педагогика. 2003. № 3. С. 3-10.

8. Компетентнісний підхід у сучасній освіті: світовий досвід та українські перспективи: б-ка 3 освіт. політ. / Н. М. Бібік та ін. К. : К.І.С., 2004. 112 с.

9. Овчарук О. В. Розвиток компетентнісного підходу : стратегічні орієнтири міжнародної спільноти. Компетентнісний підхід у сучасній освіті : світовий досвід та украӥнські перспективи. К. : «K.I.C.», 2004. $112 \mathrm{c}$.

10. Локшина О. І. «Компетентнісна» ідея в освіті зарубіжжя: успіхи та проблеми реалізації. Компетентнісний підхід в освіті: теоретичні засади і практика реалізащії : матеріали методол. семінару 3 квіт. 2014 р. - К. 2014. С. 51-59.

11. Зеер Э. Ф. Павлова А. М., Сыманюк Э. Э. Модернизация профессионального образования: компетентностный подход. М. : Московский психолого-социальный институт, 2005. 216 с.

12. Лобанова Т. Н. Построение модели ключевых компетенций. Справочник по управлению персоналом. 2002. № 11. С. 21-26.

13. Шелехова Г. Т. Розвиток комунікативної компетентності старшокласників із використанням підручника української мови. Компетентнісно спрямована освіта: перший досвід, порівняльні під-

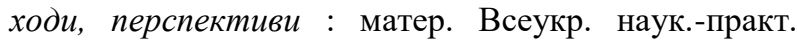
конф. К., 2011. С. 234-237.

\section{KEY COMPETENCIES COMPETENCE AS AN OBJECT OF DIDACTIC RESEARCHES \\ S. Fedorenko, L. Butko}

Kremenchuk Mykhailo Ostrohradskyi National University

vul. Pershotravneva, 20, 39600, Kremenchuk, Ukraine. E-mail: svfedor70@gmail.com

Purpose. The article provides a detailed analysis of the essence of the concept of «key competencies» and provides reasonable theoretical evidence for the need for the integrated formation of the key competencies during the educational process of the future qualified employees. Methodology. The theoretical study was made using general scientific methods: analysis and synthesis, comparison, induction and deduction, descriptions. Findings. The basic principles of the need to reform vocational education in the context of new evolutionary requirements of time are formulated. The essence of the concepts «competence», «key competence» is opened. The main list of the key competencies presented by foreign and domestic scientists was analyzed. It is noted that the problem of determining the essence and the list of key competences is rather thoroughly developed in the modern psychological and pedagogical literature. Particular attention is focused on the need for the process of training to adhere to the integrated formation of key competencies that will contribute to the formation of the personality of the future skilled worker as a high-class competitive specialist. Originality. The scientific novelty lies in the fact that the article analyzes the latest scientific applications of the modern domestic scientists. Practical value. The results of this study can take into account leading pedagogical specialists in the field of vocational education in the development of educational and professional programs and, accordingly, curricula for the training of the qualified workers. Conclusions. Key competencies are the most universal culturally developed ways of action that allow individuals to understand the situation, achieve results in their personal and professional life in a particular society, that is, practically realize their competence in a particular area. The realization that without key competences it is almost impossible for a person to fully function in society as a social subject, successfully mastering a profession and specialty, learning throughout life as an educational subject, successful realization of professional potential in professional activities as a professional subject, proves the need for their integrated formation in an educational process.

Key words: competence, key competencies, competency, vocational education, qualified worker, professional training. 


\section{REFERENCES}

1. Schröder, H., (1999), Theorie und Praxis der Erziehung, München.

2. Zyazyun, I. A. (2005), Philosophy of progress and forecast of the educational system [Filosofiya postupu i prohnozu osvitnoyi systemy. Pedahohichna maysternist: problemy, poshuky, perspektyvy : monohrafiya], RVV HDPU, Kyiv, Hlukhiv, pp. 8-10.

3. Pometun, O. I. (2005), “Competency approach - the most important benchmark for the development of the modern education", Native school ["Kompetentnisnyy pidkhid - nayvazhlyvishyy oriyentyr rozvytku suchasnoyi osvity", Ridna shkola], no 1, pp. 65-69.

4. Yahupov, V. (2012), "Key Competences: Concept, Essence, Content, Classification and Requirements for Graduates of Vocational Education", Scientific bulletin ["Klyuchevye kompetentnosty: ponyatye, sushchnost, soderzhanye, klassyfykatsyya y trebovanyya $\mathrm{k}$ vypusknykam professyonalnotekhnycheskoho obrazovanyya", Naukovyy visnyk], no 4, pp. 12-18.

5. Matusz, M. (2008), "Kompetencje informacyjne nauczycieli i uczniw", Edukacja Technika informatyka - edukacja / pod red. W. Walata, Uniwersytet Rzeszowski, Rzeszow, Tom X, Teoretyczne $i$ praktyczne problemy edukacji informatycznej, pp. 191-192.

6. Khutorskoy, A. V. (2002), "Key Competences and Educational Standards", Online magazine "Eidos" ["Klyuchevye kompetentsyy, y obrazovatelnye standarty", Ynternet-zhurnal "Éydos"], available at: http://www.eidos.ru/journal/2002/0423.htm

7. Kraevskyy, V. V. Khutorskoy, A. V. (2003), "Subject and general subject in educational standards", Pedagogics ["Predmetnoe y obshchepredmetnoe v obrazovatelnykh standartakh", Pedahohyka], no 3, pp. $3-10$.

8. Bibik, N. M. (2004), "Competency Approach in Modern Education: World Experience and Ukrainian Perspectives: brochure on educational policy" [Kompetentnisnyy pidkhid u suchasniy osviti: svitovyy dosvid ta ukrayinski perspektyvy : b-ka z osvit. Polityky], K. : K.I.S.,. 112 p.

9. Ovcharuk, O. V. (2004), "Development of a Competent Approach: Strategic Guidelines for the International Community", Competency approach in the modern education: world experience and Ukrainian perspectives ["Rozvytok kompetentnisnoho pidkhodu : stratehichni oriyentyry mizhnarodnoyi spilnoty", Kompetentnisnyy pidkhid u suchasniy osviti : svitovyy dosvid ta ukrayinski perspektyvy], "K.I.S.”, K,. 112 p.

10. Lokshyna, O. I. (2014) "Competent" idea in foreign education: successes and problems of implementation: materials of the methodological seminar Competency Approach in Education: Theoretical Foundations and Implementation Practices ["Kompetentnisna" ideya v osviti zarubizhzhya: uspikhy ta problemy realizatsiyi. Kompetentnisnyy pidkhid $\mathrm{V}$ osviti: teoretychni zasady i praktyka realizatsiyi : materialy metodol. seminaru]. (pp. 5159). K.

11. Zeer, É. F. Pavlova, A. M., Symanyuk, É. É. (2005), Modernization of vocational education: competency approach [Modernyzatsyya professyonalnoho obrazovanyya: kompetentnostnyy podkhod], Moskovskyy psykholoho-sotsyalnyy ynstytut, M., 216 p.

12. Lobanova, T. N. (2002), "Building a model of key competencies" [Postroenye modely klyuchevykh kompetentsyy], Spravochnyk po upravlenyyu personalom, No. 11, pp. 21-26.

13. Shelekhova, H. T. (2011), Development of communicative competence of senior pupils using the textbook of the Ukrainian language, All-Ukrainian Scientific and Technical Conference "Competencyoriented education: first experience, comparative approaches, perspectives" [Rozvytok komunikatyvnoyi kompetentnosti starshoklasnykiv iz vykorystannyam pidruchnyka ukrayinskoyi movy. Kompetentnisno spryamovana osvita: pershyy dosvid, porivnyal'ni pidkhody, perspektyvy : mater. Vseukr. nauk.-prakt. konf]. (pp. 234-237). K. 